Int. J. Electrochem. Sci., 15 (2020) 9707 - 9719

\title{
Corrosion Resistance of the UNS N26455 Superalloy in Simulated Environment Containing Chloride and $\mathrm{CO}_{2}$
}

\author{
José Henrique Alano ${ }^{1, *}$, Renato Luiz Siqueira, Régis Djiovanni da Cruz Rosca ${ }^{l}$, Amanda Dantas de \\ Oliveira ${ }^{2}$, Guilherme dos Santos Vacchi ${ }^{3}$, Sebastião Elias Kuri ${ }^{3}$, Ricardo Marques e Silva ${ }^{3, *}$, Carlos \\ Alberto Della Rovere ${ }^{3, *}$ \\ ${ }^{1}$ Escola de Engenharia, Universidade Federal do Rio Grande, Campus Carreiros, 96203-900, Rio \\ Grande, RS, Brazil \\ ${ }^{2}$ Centro de Desenvolvimento Tecnológico, Universidade Federal de Pelotas, Rua Gomes Carneiro 1, \\ 96010-610, Pelotas, RS, Brazil \\ ${ }^{3}$ Universidade Federal de São Carlos, Programa de Pós-Graduação em Ciência e Engenharia de \\ Materiais, Rodovia Washington Luís km 235, 13565-905, São Carlos, SP, Brazil \\ *E-mail: henrique.al@gmail.com; ricardomarqueseng@gmail.com; rovere@ufscar.br
}

doi: $10.20964 / 2020.10 .56$

Received: 4 June 2020 / Accepted: 30 July 2020 / Published: 31 August 2020

\begin{abstract}
UNS N26455 is a superalloy commonly used on offshore platforms in components for injection pumps due to its appreciable resistance to various forms of corrosion. However, this superalloy sustain damage under aggressive operating conditions, such as in the presence of chloride ions $\left(\mathrm{Cl}^{-}\right)$, harmful gases or even thermal variations. Hence, the corrosion resistance of UNS N26455 was evaluated via the anodic potentiodynamic polarization technique to understand its behavior under potentially harmful working conditions. The experiments were carried out in controlled environments containing high $\mathrm{Cl}^{-}$concentrations at different temperatures $\left(25\right.$ and $\left.40{ }^{\circ} \mathrm{C}\right)$, with and without carbon dioxide $\left(\mathrm{CO}_{2}\right)$ saturation. The results confirmed that the as-cast superalloy is highly resistant to localized corrosion. On the other hand, the influence of the formation of its microstructure's secondary phase, which occurs when it is exposed to high temperatures for a prolonged period of time, still needs to be investigated properly.
\end{abstract}

Keywords: nickel superalloy, corrosion resistance, anodic polarization.

\section{FULL TEXT}

(C) 2020 The Authors. Published by ESG (www.electrochemsci.org). This article is an open access article distributed under the terms and conditions of the Creative Commons Attribution license (http://creativecommons.org/licenses/by/4.0/). 